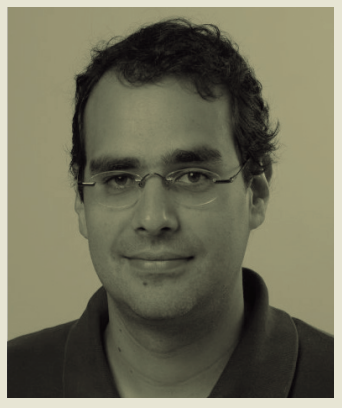

\title{
MACHO, ADULTO E BRANCO
}

(U) ma jovem recém-contratada como trainee participava de uma reunião de boas vindas em seu novo emprego, uma grande empresa historicamente comandada por engenheiros. Perfilados na mesa de honra do auditório, estavam o presidente e os diretores corporativos da companhia, todos do sexo masculino, brancos e de meia idade. Para o desespero da gerente de Recursos Humanos, a trainee levou a sério o fato de que poderia perguntar o que quisesse. Levantou a mão e sapecou: "Vejo apenas homens sentados nas posições de comando. Uma mulher, como eu, tem alguma chance?". Silêncio no auditório.

A história contada por um amigo que estava no recinto durante o acontecimento mostra uma realidade ainda presente nas empresas do nosso país: homens brancos são a maioria entre as pessoas que ocupam cargos de chefia. Questionar o patriarcado organizacional gera desconforto.

No último mês de junho, assistia na Universidade de Gotemburgo (Suécia) a um seminário com as professoras Marta Calás e Linda Smircich, ambas docentes da Universidade de Massachusetts (EUA) e pioneiras em

ORGANIZAÇÕES SÃO AMBIENTES NOS QUAIS HOMENS PODEM MOSTRAR SEU PODER E MULHERES PRECISAM ADOTAR UMA POSTURA MASCULINA PARA CRESCER NA HIERARQUIA
O que parece um discurso clichê é a mais pura realidade, apesar de todo o falatório em contrário. Ana Paula Diniz, mestre pela Universidade Federal de Minas Gerais (UFMG), explicita, em sua excelente dissertação de mestrado, discursos gerenciais-administrativos que atuam sobre as mulheres e as constituem como desprivilegiadas no espaço de trabalho. Dados do Censo 2010 indicam que as profissionais do sexo feminino ganham $30 \%$ menos do que os homens no Brasil. Apesar delas representarem metade da população, ocupam apenas $20 \%$ das posições de comando no País.

Além disso, cada vez mais executivas abrem mão de ter uma família em nome da carreira. É comum que profissionais com filhos recém-nascidos tenham que trabalhar de casa já nas primeiras semanas após o nascimento de seu rebento. As organizações brasileiras raramente respeitam como desejo legítimo o fato da mulher querer constituir uma família.

O comando masculino é também heterossexual. Diversos estudos mostram que homens e mulheres homossexuais precisam esconder sua vida íntima no ambiente de trabalho. Qual seria a reação de executivos heterossexuais se um colega aparecesse em um jantar da corporação com seu companheiro ou companheira do mesmo sexo? Organizações em geral e empresas em particular são lugares nos quais ser homem e heterossexual é uma vantagem. O mesmo se aplica às questões de raça. Os brancos de ascendência europeia são a maioria nas posições de chefia. $\mathrm{O}$ macho, adulto e branco segue no comando. A grande questão é o motivo de tamanhas discrepâncias existirem até hoje. 